Original Research

\title{
Evaluation of Clinical Nursing Practice Programme with Preceptorship Supervision (Stake's Countenance Evaluation Model)
}

\author{
Syamsul Anwar ${ }^{1}$, Yetti Supriyati ${ }^{2}$ and Burhanuddin Tolla ${ }^{2}$ \\ ${ }^{1}$ Student Doctoral Program, Education Research and Evaluation, Universitas Negeri Jakarta \& Lecture, Faculty \\ Nursing, Universitas Muhammadiyah Jakarta \\ ${ }^{2}$ Lecture, Doctoral Program, Universitas Negeri Jakarta
}

\begin{abstract}
Introduction: Preceptorship is clinical education for nursing students by conducting constructive partnerships between nurse educators and practitioners. Therefore, the purpose of this study was to find out the effectiveness of the preceptorship programme using the Stake Model Evaluation Programme in terms of aspects antecedents, transactions, outcomes and behaviours.
\end{abstract}

Methods: This study uses descriptive design with quantitative and qualitative approaches. The sample consists of 131 students, 22 clinical preceptors and 22 academic preceptors. The quantitative data were collected using questionnaires, observation and document studies. Qualitative study was conducted using an interview. Descriptive analysis uses mean, standard deviation, percentage, frequency distribution and qualitative analysis using a content analysis.

Results: The study evaluation found that at antecedent stage. About $68.2 \%$ to $90.9 \%$ clinical preceptors had a good preparation on the student preparation stages as perceived by the academic preceptor and preceptee. While in the stage of transaction, preceptors are able to teach nursing care and students to perform nursing care from simple to complex in accordance with the competencies achieved. Only less than half (45.5\%) of students had good implementation of nursing care, including assessment, diagnosis, planning, implementation and evaluation. However, more than $68 \%$ of them showed good professional attitudes and communication. The outcome phase obtained consistency in the result of the practice phase with the national competency test with value from $76.2 \%$ to $97.4 \%$.

Conclusion: The majority of the antecedent, transaction stage, and outcome showed an average condition which requires an improvement in order to provide a good quality education programme. Future studies may also need to design an alternative approach for students' supervision in clinic.

\section{ARTICLE HISTORY}

Received: June 24, 2019

Accepted: Nov 23, 2019

\section{KEYWORDS}

attitude; preceptee; preceptor; preceptorship; stake's countenance

\section{CONTACT}

Syamsul Anwar

$\triangle$ syamsul_nisa@yahoo.co.id

$\equiv$ Faculty Nursing, Universitas

Muhammadiyah Jakarta, Jakarta,

Indonesia

Cite this as: Anwar, S., Supriyati, Y., Tolla, B. (2019). Evaluation of Clinical Nursing Practice Programme with Preceptorship Supervision (Stake's Countenance Evaluation Model). Jurnal Ners, 14(1),75-81. doi:http://dx.doi.org/10.20473/jn.v14i1.13908

\section{INTRODUCTION}

Clinical learning with a preceptorship learning model is carried out by pairing between experienced nurses (preceptors) and nursing students (preceptees) over a certain period of time which has been previously determined. Preceptorship aims to develop personal skills, communication, clinical skills, competence and self-confidence of nursing students when implementing nursing care (Al-Hussami, Saleh, Darawad, \& Alramly, 2011; Jordan \& Farley, 2008; Kim, 2007; Mason \& Davies, 2013; Yueju, 2005). Preceptorship also teaches ethical dimensions and 
integrates both theory and practice (Bengtsson \& Carlson, 2015). Preceptorship is also effective in achieving teaching goals so that ultimately the knowledge, skills and attitudes needed for nursing care are obtained (Mcclure \& Black, 2013;Varley, MacNamara, \& Mannix-MacNamara, 2012).

The clinical teaching programme also teaches students to organise patient care and be able to build good communication with other staff. In the clinical setting, clinical nurses help the process in integrating and applying the role of professional nursing (Murphy, 2014). Clinical nurses also provide supervision to students and help them to apply the theoretical values obtained in academic studies(Azizah \& Ropyanto, 2012; Moyle, Rickard, Chambers, \& Chaboyer, 2015). During the process of the ongoing programme, clinical nurses in conducting supervision must have good skills, good nursing care abilities and clinical experience so that the learning process become effective (Dahlia, Harun, \& Usman, 2013). Thus, by promoting a constructive partnership between nurse educators and clinical nurses, the knowledge transfer process during the preceptorship will run well (Kaviani \& Stillwell, 2000).

The preceptorship supervision model conducted by Faculty of Nursing Muhammadiyah University in Jakarta obtained a preliminary study which showed that supervision conducted by clinical supervisors was not optimal due to limited time to supervise. Furthermore, $80 \%$ of the preceptors have many duties to do besides being preceptors; they are also care givers to their patients, so the supervision given to the students becomes ineffective. Thus, the preceptors also work in shifts (morning, evening and night), so, in some cases, the supervision is represented by a staff nurse. The preliminary studies obtained that $45 \%$ of students said that they had not been optimal in nursing care, 55\% were able to do nursing care, $75 \%$ of students' skills were good and $25 \%$ had sufficient skills (FIK UMJ, 2015). Another study related to the effect of motivation from nursing supervisors towards students' readiness to carry out clinical practice showed that $41.5 \%$ of students have good motivation and are ready to practice in the hospital and $58.5 \%$ are not ready $(\mathrm{p}=0.008, \mathrm{p}<$ 0.005) (Pertiwi \& Ermayani, 2017).

According to the results of preliminary studies and previous studies, we need evaluation to gather information about the implementation of the preceptorship on policies, the process carried out and the results of the programme (Arikunto, 2008). The evaluation is needed to provide suggestions to policymakers so that these can be followed up in the future. Thus, future prepared programmes can be useful for the recipient (Ayurestianti, 2017). Evaluation of this study used the evaluation process analysis designed by Stake in 1967 (Stufflebeam \& Coryn, 2014). This model also considers various dimensions and factors which have an impact on teaching and learning, quantitative and qualitative approaches (Joseph \& Juwah, 2012).

\section{MATERIALS AND METHODS}

The method used in this study is descriptive evaluation study approach with quantitative and qualitative approaches since the result of the study assessed the implementation of the preceptorship on policies, the process carried out and the results of the programme (Brannen \& Brannen, 2017; Nasional Departemen Pendidikan, 2008,). Descriptive evaluation study is a research that has an aim to provide information for decision-makers (policy makers) related to a power or strength of a programme, seen from its effectiveness, cost, device, etc. Descriptive research studies are designed to obtain the nature of the situation as it exists at the time of the study. Thus, the aim of descriptive research is to describe what exists (Ary, 1990). Evaluation of this model consists of three stages, contexts (antecedents), processes (transactions) and results (outcomes). The evaluation format was developed by the team through extensive literature review and expert discussion. Antecedents were focussed on preparation through preclinical test stage, curriculum and assessment of the facilities and infrastructure. Transaction was related to the implementation of the supervision process from preceptors to students, competency achievement, implementation of nursing care, professional attitude, outcome and the results of a try out test conducted by AIPNI.

This study was approved by the Institutional Review board and Research and Development from the affiliated university and information passed the ethics test number 0397A /F.9-UMJ /V/ 2016. Data collection techniques used for quantitative study were questionnaire observation, documentation and attitude test scale (Sukardi, 2014). Qualitative study used an interview to explore more about the situation according to the informants' experience and point of view. Sample of this study consists of 131 students, 22 clinical preceptors and 22 academic preceptors. This study took place at Islamic Alliance Hospital Jakarta from May 2016 to November 2016. Qualitative data were analysed using a content analysis, while quantitative data were described using a proportion for categorical data and mean and standard deviation for continuous data.

Table 1. Antecedent Evaluation $(n=131)$

\begin{tabular}{lcc}
\hline Indicator & $\mathbf{f}$ & $\mathbf{\%}$ \\
\hline Clinical Preceptor & & \\
$\quad$ Sufficient & 7 & 31.8 \\
$\quad$ Good & 15 & 68.2 \\
$\quad$ Total & 22 & 100.0 \\
Academic Preceptor & & \\
$\quad$ Sufficient & 2 & 9.1 \\
$\quad$ Good & 20 & 90.9 \\
$\quad$ Total & 22 & 100.0 \\
Preceptee (Students) & & \\
$\quad$ Sufficient & 24 & 18.3 \\
$\quad$ Good & 107 & 81.7 \\
$\quad$ Total & 131 & 100.0 \\
\hline
\end{tabular}




\section{RESULTS}

\section{Antecedents}

\section{The foundation of the Professional Nurse Programme}

The results of interview with Dean of Faculty of Nursing Muhammadiyah University Jakarta are reported as follows:

"The clinical learning programme with preceptorship supervision model referred to the competency-based curriculum (curriculum basic competency) in 2010 which implements a professional programme inseparable from the academic programme by strengthening all the competencies."

\section{Students' preparation through preclinical test stage}

The result of the preclinical test showed the average score of 131 students was 74.00. The evaluation of students' preparation at antecedent stage was done by clinical preceptors, academic preceptors and students themselves by filling in questionnaires. Table 1 shows the clinical preceptor assessment of students in the antecedent stage as preparation of preceptorship in the hospital, showing $68.2 \%$ with good evaluation. The assessment of academic preceptors to students showed $90.9 \%$ with good evaluation. Thus, $81.7 \%$ students assessed them themselves with good evaluation.

\section{Curriculum}

Interview with Dean of Faculty of Nursing Muhammadiyah University Jakarta

"The education curriculum consists of the academic and professional stages curriculum, covering $60 \%$ of the core curriculum and $40 \%$ of the institutional curriculum. The institutional curriculum represents the speciality of each institution, which consists of 50\% global ability and 50\% intuitional ability. The output of professional nurses' education curriculum must guarantee the achievements of competencies in accordance with the Indonesian National Qualification Framework (IQF) rank 7."

The curriculum used refers to the study programme curriculum, which refers to the core curriculum of Indonesian Professional Nurse Education with Indonesian National Qualification Framework at 7th level, which consists of two stages of education, academic stage and professional nurse stage.

\section{Assessment of facilities and infrastructure}

This assessment used an observation sheet which includes the assessment of hospital land facilities $(\bar{x})=68$ with maximum score of $80 \%$, and then categorised with the normal distribution model $\bar{x} \geq$ $(\mu+1,0 d)=\bar{x} \geq 62.33$. The conclusion category is good hospital and academic facilities.

\section{Transactions}

\section{Implementation process}

The results of the implementation process of the preceptorship programme activities are obtained as follows:

Student orientation; the interview is conducted to the clinical supervisors who conduct orientation to students.

... Students who have been introduced have begun to participate in orientation activities. The implementation began with three students divided based on their competences, (P5) ...When they got instructions from the campus, the contract continued to the implementation phase, where the clinical supervisors held orientation as part the requirement for students to practice in the hospital ( $P 7)$

Clinical preceptors are required to carry out the orientation process to students because the students need to be introduced to the hospital profile, both its vision and mission, its rooms, operational standard procedures, target of competencies, patient safety and nurse safety while give nursing care to patients.

Supervision process from preceptors in regard to students

Interview with the Dean of Faculty of Nursing Muhammadiyah University Jakarta about the implementation process:

...Students meet the clinical supervisors and conduct a learning contract with them so both sides know their needs from each other in this learning programme.

Academic preceptors in collaboration with clinical preceptors provide gradual implementation, not carried out sporadically, from simple to complex activities.

Interview with academic preceptors about their supervision.

... The supervision process is certainly applied in preceptors' activities where the learning process is from simple to complex. Students are also taught how to do one simple procedure, from understanding the procedure to how to perform it.

Learning from simple to complex is a part of the learning programme which moves from the easy part to the difficult part. This programme helps students to develop their ability from the cognitive and psychomotor side. Furthermore, it can increase their self-confidence in managing cases.

\section{Competency achievement}

Interview with academic supervisors about competencies attained by students

... Students are asked to make learning contracts, which explain competencies and what will be completed. Academic supervisors prepare BPKM for students and supervisors. 
Table 2. Nursing Care Implementation Evaluation

\begin{tabular}{|c|c|c|c|c|c|c|c|c|c|c|}
\hline \multirow{2}{*}{ Preceptor } & \multicolumn{2}{|c|}{ Assessment } & \multicolumn{2}{|c|}{ Diagnosing } & \multicolumn{2}{|c|}{ Planning } & \multicolumn{2}{|c|}{ Implementation } & \multicolumn{2}{|c|}{ Evaluation } \\
\hline & f & $\%$ & f & $\%$ & f & $\%$ & f & $\%$ & $\mathbf{f}$ & $\%$ \\
\hline \multicolumn{11}{|l|}{ Academic } \\
\hline Sufficient & 11 & 50 & 10 & 45.5 & 4 & 18.2 & 7 & 31.8 & 9 & 40.9 \\
\hline Good & 11 & 50 & 12 & 45.5 & 18 & 81.8 & 15 & 68.2 & 13 & 59,1 \\
\hline Total & 22 & 100 & 22 & 100 & 22 & 100 & 22 & 100 & 22 & 100 \\
\hline \multicolumn{11}{|l|}{ Clinic } \\
\hline Sufficient & 7 & 31.8 & 10 & 45.5 & 6 & 27.3 & 8 & 36.4 & 12 & 54.5 \\
\hline Good & 15 & 68.2 & 12 & 45.5 & 12 & 72.7 & 14 & 63.6 & 10 & 45.5 \\
\hline Total & 22 & 100 & 22 & 100 & 22 & 100 & 22 & 100 & 22 & 100 \\
\hline \multicolumn{11}{|l|}{ Students } \\
\hline Sufficient & 7 & 19.1 & 35 & 26.7 & 19 & 14.5 & 27 & 20.6 & 32 & 24.4 \\
\hline Good & 106 & 80.9 & 96 & 73.3 & 112 & 85.5 & 104 & 79.4 & 99 & 75.6 \\
\hline Total & 131 & 100 & 131 & 100 & 131 & 100 & 131 & 100 & 131 & 100 \\
\hline
\end{tabular}

Table 3. Evaluation of Professional Attitudes and Communication

\begin{tabular}{|c|c|c|c|c|c|c|c|c|c|}
\hline \multirow{3}{*}{$\begin{array}{l}\text { Respondents } \\
\text { Evaluation }\end{array}$} & \multirow{3}{*}{ Category } & \multicolumn{7}{|c|}{ Competence Score } & \multirow[b]{3}{*}{ SD } \\
\hline & & \multicolumn{4}{|c|}{ Professional Attitude } & \multicolumn{3}{|c|}{ Communication } & \\
\hline & & f & $\%$ & Mean & SD & f & $\%$ & Mean & \\
\hline \multirow[t]{3}{*}{ Students } & Sufficient & 20 & 15.3 & \multirow{3}{*}{16.6} & \multirow{3}{*}{2.2} & 21 & 16 & \multirow{3}{*}{20} & \multirow{3}{*}{2.52} \\
\hline & Good & 111 & 94.7 & & & 110 & 84 & & \\
\hline & Total & 131 & 100 & & & 131 & 100 & & \\
\hline Academic & Sufficient & 5 & 22.7 & \multirow{3}{*}{16} & \multirow{3}{*}{2.44} & 4 & 18.2 & \multirow{3}{*}{28} & \multirow{3}{*}{3.44} \\
\hline \multirow{2}{*}{ Preceptors } & Good & 7 & 77.3 & & & 18 & $\begin{array}{l}10.2 \\
81.8\end{array}$ & & \\
\hline & Total & 22 & 100 & & & 22 & 100 & & \\
\hline Clinical & Sufficient & 7 & 31.8 & \multirow[b]{2}{*}{15.7} & \multirow{2}{*}{2.46} & 9 & 40.9 & \multirow{2}{*}{26.54} & \multirow{2}{*}{2.46} \\
\hline Preceptors & Good & 15 & 68.2 & & & 13 & 59.1 & & \\
\hline
\end{tabular}

Besides competencies and evaluation, BPKM also contains implementation of supervision and evaluation ... (P1)

...Usually in a hospital, there are several wards where we will move students around and, for some wards, we cannot write down students' competencies targets because it is determined on the majority of cases there....

The achievement of student competencies is written structurally in the students' activity guidebook. Besides the list of students' competencies, the guideline book also contains the programme contract between students and clinical supervisors and then students and the academic supervisor regarding the competency targets to be achieved. But, if it is constrained, the clinical supervisor will roll out the students so they can get the competencies in other wards. Thus, if there is no competency in the wards, it will be dealt with in discussion activities or case study presentation in the campus.

\section{Implementation of nursing care}

Implementation of nursing care evaluated by the academic supervisors can be seen in Table 2 .

Table 2 is obtained from assessment of 22 academic supervisors in regard to students' nursing care implementation. In general, $50 \%$ of students are categorised with good ability with formulation, $45.5 \%$ with good ability of formulating diagnosis, $81.8 \%$ with good ability of planning the interventions, $68.2 \%$ with good ability to implement their interventions, and $59.1 \%$ with good evaluation.

Thus, the result of students' assessment (131 students) to their performance shows $80.9 \%$ students with good ability, 73.3\% can formulate diagnosis well,
$85.5 \%$ can make good nursing care plans, $79.4 \%$ can implement the interventions well, and $75.6 \%$ perform good evaluation.

During the interview, students said;

... When carrying out our clinical practice, the head nurse gave us several case to take and manage. We were given the opportunity to follow and observe the preceptors' while performing nursing care. Then, after the preceptor thought we were capable enough to perform nursing care, she/he let us do the intervention and achieve our competency targets. (P6).

The implementation of preceptorship makes the preceptors become mentor and supervisor to the students to perform nursing care to patients. They helped students by providing examples of implementing nursing care and gave students chances to perform nursing intervention (still under supervision).

\section{Professional attitude}

The result for assessment of professional attitudes and communication performed by students, clinical preceptors and academic preceptors are obtained at Table 3. The results of the assessment of professional attitudes and communication by 131 preceptees on themselves reached good values, $94.7 \%$ and mean average 16.6 Assessment of communication was good at $84 \%$ and mean attitude of communication 20 . Assessment of professional attitudes and communication of 22 academic preceptors towards students achieving good grades was $77.3 \%$ with mean average professional attitude. Communication assessment was $81.8 \%$ with mean communication 
attitudes 28. The assessment of professional attitudes and communication of 22 clinical preceptors on students reached a good score of $68.2 \%$ with a mean professional attitude of 15.7. Communication assessment was $59.1 \%$ with mean communication attitudes 26.54 .

\section{Outcome}

Final evaluations of the preceptorship programme are from odd semester and even semester in academic year 2016/2017. Graph 1 shows the distribution of average score from students of odd semester academic year 2016/2017 with the highest score obtained by the nursing seminar course with a score of 4.0, while the lowest average score was obtained by the emergency nursing with a score of 3.16. Thus, for students in the even semester, the highest average score belongs to community health nursing with a score of 3.88 and the lowest average score is in emergency nursing with a score of 3.33. Furthermore, the highest GPA for the odd semester was 4 and the lowest was 3.14, average GPA 3.47. The highest GPA for even semester was 4 and the lowest GPA was 3, average GPA 3.53.

\section{Result of try out test conducted by AIPNI}

The result of a try out test held on February 4, 2017 by the Indonesian Nursing Higher Education Association obtained results with the highest score of 72.2 in 2017 and the lowest score of 26.1. The competency test results of the preceptors' programme in odd semester and 2016/2017 academic year were even obtained with graduations of $76.2 \%$ and the odd semester $2016 / 2017$ academic year were obtained by graduating $97.4 \%$

\section{DISCUSSION}

The professional nurse programme with a preceptorship programme uses a competency-based curriculum (CBC or KBK) 2010, whereby students will be transplanted to senior nurses, namely preceptors. Grafting students in this programme secures the supervision of their senior nurses. The aim of the clinical programme is to develop the knowledge, understanding and skills of new nurses to meet the requirements to work at a hospital. The progress and experience of new nurses can be monitored by ensuring their competence and satisfaction during their first year in clinical practice (Forde-Johnston, 2017). This process is called the transition phase, then, to facilitate this transition, preclinical programmes need to be implemented to encourage professional socialisation and help students achieve a level of trust in practice. Preclinical exams or training will enhance the full-time practical experience with clinical preceptors (Bourbonnais \& Kerr, 2007). Students in their clinical practice need preceptors in order to obtain the competency skills needed to carry out care in safely, competently and with professional ethics in providing nursing care at the hospital. Nursing care can improve student competences and increase knowledge about clinical teaching ( Al-Hussami et al., 2011; Kim, 2007). On the other hand, to be preceptors, there are several criteria needed, including attitudes and behaviours, which include positive, patient and supportive behaviour, in addition to having the desire to motivate and inspire (Anderson, 2008; MOH, 2004; Smedley, 2008; Zilembo \& Monterosso, 2008 cited in Haggerty, Holloway, \& Wilson, 2013). The implementation process begins with the experience of students providing care to patients or assigned clients and having assistance, guidance and support from the supervisor. When competencies gradually increase, students assume more responsibility until they are able to carry out nursing tasks that are on par with a

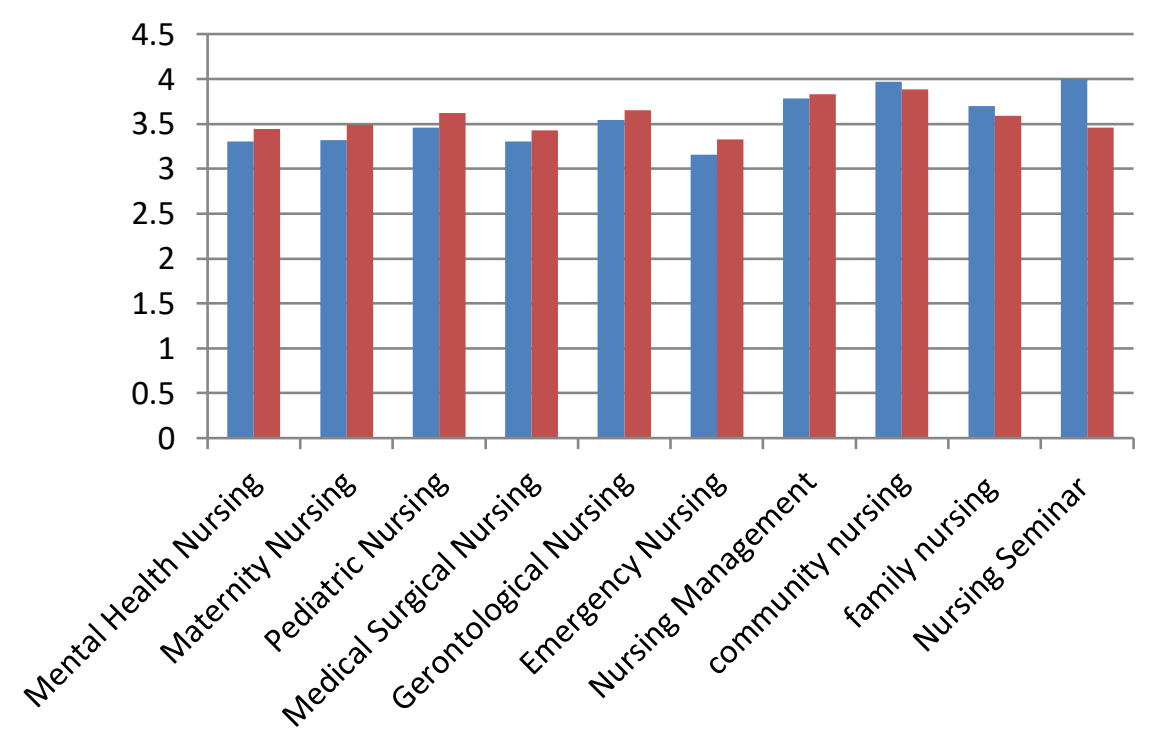

Average score odd semester 2016/2017

Average score even semester 2016/2017

Graph 1. Students Average Score Odd Semester and Even Semester Academic Year 2016/2017 
novice practitioner in the chosen setting (Bourbonnais \& Kerr, 2007).

This study found that students' preparation through preclinical test stage had a good preparation ranged from $68.2 \%$ to $90.9 \%$ as perceived by the academic preceptor and preceptee. The transition from classroom to clinical commonly makes a student feel fear or uncertainty (Ham, 2004). To deal with this situation, nursing education should set the academic process or learning process that could facilitate students to have an opportunity to apply and refine the cognitive ability with affective and psychomotor skills. Clinical training takes place in a complex social sense in which an educator takes care of the needs of patients, students and clinicians. However, previous study suggested that there were factors influencing the clinical preparation of nursing student interns, namely educator incompetency, nursing staff technical ability and a non-conducive learning environment (Cheraghi, 2008). Therefore, in designing clinical preparation for nursing practice there is need to consider competency of educators, technical ability and learning environment.

This study also provides information on the ability of nursing students about the implementation of nursing care, including assessment, diagnosis, planning, implementation and evaluation. Less than half of students showed good performance on these aspects. Nursing students in particular often question why developing care plans is such an integral part of their education and training. This condition could happen due to nursing documentation covering a wide variety of issues, topics and systems; therefore, different hospitals or wards could have different styles or formats. Given the problems of designing a care planning system that works well for nurses alone, it is understandable why it is much more difficult to build integrated systems that support interdisciplinary plans.

\section{CONCLUSION}

This study discusses the evaluation of the preceptorship programme in the Faculty of Nursing, Muhammadiyah Jakarta, which includes antecedents, transaction and output/evaluation. The first stage, antecedents (context preparation), includes student evaluation, academic supervisors, clinical supervisors, curriculum, programme foundation, facilities and infrastructure. Next is the transaction (process) and the guidance process is carried out following the clinical supervisor; the supervisor carries out activities customised to suit the competencies to be achieved by the student. In the process, the supervisors carry out the process of delegation; the stages carried out consist of student orientation and academic supervisors collaborating with clinical supervisors to provide supervision for students. The third stage, output / evaluation, is where evaluation conducted includes cognitive assessment, skills and competency tests, professional attitudes and communication, and behavioural attitudes. Those objects of evaluation have criteria and standards which have been established from the beginning of evaluation and clinical behaviour as indicators to rank for clinical competencies (e.g. accountability, attitudes, judgements, communication). Finally, the supervisors evaluate the students based on those evaluation criteria and ultimately ensure accuracy and consistency between student evaluations. This study suggested that, in designing clinical preparation for nursing practice, there is need to consider competency of educators, technical ability and learning environment. To improve the implementation of nursing care for students during their clinical practices, it is required to develop or create a new model in classroom teaching, for example, using virtual reality or using an actual case to help students have an overview about clinical situations and what they have to do as nurse. Future studies may also need to design an alternative approach for students' supervision in clinic.

\section{REFERENCES}

Al-Hussami, M., Saleh, M. Y. N., Darawad, M., \& Alramly, M. (2011). Evaluating the Effectiveness of a Clinical Preceptorship Program for Registered Nurses in Jordan. The Journal of Continuing Education in Nursing, 42(12), 569576. https://doi.org/10.3928/0022012420110901-01

Arikunto, S. (2008). Evaluasi Program Pendidikan. PT Bumi Aksara. https://doi.org/10.1109/TEVC.2004.826389

Ary, D. (1990). Introduction to Research in Education $4^{\text {th }}$ edn. NY: Harcourt Brace College Publishers.

Ayurestianti. (2017). Evaluasi Pelayanan Kesehatan Dan Pendidikan Program Keluarga Harapan (Pkh). Masyarakat, Jurnal Pemberdayaan Pemikiran, Media Pembangunan, Dakwah, 1(2), 423-442. https://doi.org/10.14421/jpm.2017.012-10

Azizah, L. K., \& Ropyanto, C. B. (2012). Tingkat Kepuasan Bimbingan Klinik Mahasiswa. Journal of Nursing Studies, 1(1), 219-224.

Bengtsson, M., \& Carlson, E. (2015). Knowledge and skills needed to improve as preceptor: development of a continuous professional development course - a qualitative study part I. BMC Nursing, 1-7. https://doi.org/10.1186/s12912-015-0103-9

Bourbonnais, F. F., \& Kerr, E. (2007). Preceptoring a student in the final clinical placement: Reflections from nurses in a Canadian Hospital. Journal of Clinical Nursing, 16(8), 1543-1549. https://doi.org/10.1111/j.13652702.2006.01828.x

Brannen, J., \& Brannen, J. (2017). Mixing Methods: The Entry of Qualitative and Quantitative Approaches into the Research Process.International Journal of Social Research Methodology, 8(3), 173-184, https://doi.org/10.1080/13645570500154642 
Cheraghi, M. A, Salasli, M, \& Ahmadi,F. (2008). Factors influencing the clinical preparation of BS nursing student interns in Iran. International Journal of Nursing Practice, 14 (1), 26-33. doi: 10.1111/j.1440-172X.2007.00664.X.

Dahlia, S., Harun, C. Z., \& Usman, N. (2013). The Performance of Clinical Instructor toward Nursing Internship Students at Mental Hospital of Aceh Government. Idea Nursing Journal, IV(1), 817.

Forde-Johnston, C. (2017). Developing and evaluating a foundation preceptorship programme for newly qualified nurses. Nursing Standard, 31(42), 42-52. https://doi.org/10.7748/ns.2017.e10413

Haggerty, C., Holloway, K., \& Wilson, D. (2013). How to grow our own: An evaluation of preceptorship in New Zealand graduate nurse programmes. Contemporary Nurse, 43(2), 162-171. https://doi.org/10.5172/conu.2013.43.2.162

Ham, K, \& O’Rourke, E. (2004). Clinical Preparation for Beginning Nursing Students: An Experiential Learning Activity. Nurse Educator, 9 (4), 139-141. DOI: $10.1097 / 00006223-200407000-00006$

Jordan, R., \& Farley, C. L. (2008). The Confidence to Practice Midwifery: Preceptor Influence on Student Self-Efficacy. Journal of Midwidery and Women's Health, 53(5), 413-420 https://doi.org/10.1016/j.jmwh.2008.05.001

Joseph, S., \& Juwah, C. (2012). Using constructive alignment theory to develop nursing skills curricula. Nurse Education in Practice, 12(1), 5259. https://doi.org/10.1016/j.nepr.2011.05.007

Kaviani, N., \& Stillwell, Y. (2000). An evaluative study of clinical preceptorship. Nurse Education Today, $20(3)$, 218-226. https://doi.org/10.1054/nedt.1999.0386
Kim, K. H. (2007). Clinical Competence Among Senior Nursing Students After Their Preceptorship Experiences. Journal of Proffesional Nursing, 23(6), 369-375. https://doi.org/10.1016/j.profnurs.2007.01.019

Mason, J., \& Davies, S. (2013). A qualitative evaluation of a preceptorship programme to support newly qualified midwives. Evidence-Based Midwifery, 11(3), 94-98.

McClure, E., \& Black, L. (2013). The Role of the Clinical Preceptor: An Integrative Literature Review Background. Journal of Nursing Education,52(6), 335-341. https://doi.org/10.3928/0148483420130430-02

Moyle, W., Rickard, C. M., Chambers, S. K., \& Chaboyer, W. (2015). The Partnering with Patients Model of Nursing Interventions. Healthcare (Basel),3(2), 252-262. https://doi.org/10.3390/healthcare3020252

Murphy, B. E. (2014). Positive Precepting: Preparation Can Reduce the Stress. Medsurg Nursing, 17(3), 183-188.

Nasional Departemen Pendidikan (2008). Pendekatan, jenis, dan metode penelitian pendidikan. Direktorat Jenderal Peningkatan Kependidikan, Pendidik Dan Tenaga Nasional, Departemen Pendidikan. Retrieved from

Stufflebeam, D.L, \& Coryn, C. L. S. (2014). Evaluation theory, models \& application (2nd edn.). San Francisco: Jossey-Bass.

Varley, L., MacNamara, C., \& Mannix-MacNamara, P. (2012). Preceptorship: exploring the experiences of final year student nurses in an acute hospital setting.Journal of Hospital Aministration, 1(2), 42-53. https://doi.org/10.5430/jha.v1n2p42 